\title{
\begin{tabular}{l|l} 
Brexit \\
Institute
\end{tabular}
}

WORKING PAPER N. 12-2018

\section{Assessing the democratic legitimacy of the 2016 Brexit referendum}

\author{
Sandra Kröger
}

\begin{abstract}
This contribution addresses the input legitimacy of the British EU membership referendum of June 2016. It considers who was given a vote in the first place, and whether those given a vote could make a reasonable choice in light of the campaign. More precisely, it assesses the following four criteria: the franchise, the presence of clarity, the amount and quality of information, and the quality of public debate, arguing that instances of direct democracy, such as referendums, require higher standards of civic behaviour from both elected representatives and voters than those required of representative democracy. The empirical analysis of these criteria shows that the referendum fell short regarding the first two criteria whilst it could have done better as regards the last two. The paper concludes by briefly discussing what can be learnt from this referendum for future referendums.
\end{abstract}

Keywords: Brexit, democratic legitimacy, European Union, input legitimacy, referendum 


\section{Assessing the democratic legitimacy of the 2016 Brexit referendum}

\section{Introduction}

Much has been said about the referendum on British membership of the EU since the $23^{\text {rd }}$ of June 2016 (Armstrong 2017; Clark, Goodwin and Whiteley 2017; Curtice 2017; Glencross 2016; Goodwin and Milazzo 2017; Gormley-Heenan and Aughey 2017; Hobolt 2016; Hopkin 2017, amongst many others). Commentators have mostly focused on the demographics of the result as well as the factors that determined voters' choices. By contrast, there has been little scholarly reflection on how democratically legitimate the referendum process can be said to be (but see Bellamy 2018), not least because this type of reflection can only follow the availability of research results about the campaign. The legitimacy of the referendum process therefore forms the topic of this contribution ${ }^{1}$. It thereby not only helps to close a research gap. It also opens reflection on what can be learned from the 2016 referendum for future referendums.

Though many will not agree, I consider that it is possible to argue that a 'good' referendum which meets certain criteria can strengthen the democratic legitimacy of a contentious policy, such as remaining or leaving the European Union (EU) (Rose 2013). My aim here, however, is not to discuss the legitimacy of referendums per se. Instead, I shall look at how democratically legitimate the referendum process can be said to be if we consider that its legitimacy is linked to certain criteria. I appreciate that there is a wealth of relevant criteria one could look at and that as a result, not everyone will agree with the selected criteria. For instance, one might want to address the role Parliament plays in the process (Chalmers 2017); or the no less important constitutional questions of how to deal in a democratically legitimate way with different majorities in the devolved regions or of which role the devolved nations should play in the process of leaving the EU (McHarg and Mitchell 2017; Soares 2016). I do not dispute in the least that these and other questions are democratically relevant, they are just not the focus of this paper. Instead, I shall address questions of input legitimacy that consider who was given a vote in the first place, and whether those given a vote could make a reasonable choice in light of the campaign. Why this focus on input legitimacy?

\footnotetext{
${ }^{1}$ Dr Sandra Kröger, Department of Politics, University of Exeter (Amory Building, Rennes Drive, Exeter, EX4 4RJ, United Kingdom. Phone: +44-1392-263285 Mail: S.Kroeger@exeter.ac.uk.) I would like to thank Richard Bellamy, Chris Lord and Albert Weale for their constructive engagement with an earlier version of the paper which helped me improve it. The usual disclaimer applies.
} 
First, democracy is more than a formal framework which assures formal rights to citizens and that those in power are elected in free, fair and recurring elections. Democracy is also about processes seeking to make sure that all citizens have opportunities to participate in politics, to voice their opinions and influence political decision-making, and to ensure that all citizens and their interests are represented (Dahl 1989). Of course output legitimacy in general also matters for democracies. However, given that democratic processes are instituted to decide matters that people disagree about - such as whether to belong to the EU - the core of their legitimacy rests on there being a fair process to decide these disputed matters, so that the results will be acceptable also to the 'losers' of a specific decision. Second, referendums are widely discussed as a means of increasing the input legitimacy of democracies, so focusing on input legitimacy seems reasonable. Third, focusing on the outcome of the referendum could be reasonably accused of being biased, suggesting that one would argue that it was democratic if the outcome was to one's liking and not democratic if it was not.

The paper proceeds as follows. I will first develop criteria of input legitimacy as discussed in democratic theory: 1) the franchise, 2) presence of clarity, 3) amount and quality of information, and 4) the quality of public debate. In a next step, I will explore whether the Brexit referendum lived up to these four criteria. In so doing, I will primarily draw on available research findings, which implies that the assessment is by definition restricted by that literature and its findings. Second, and as a result, the assessment of the quality of information and debate are relative rather than absolute, implying that the interpretation is also relative. The empirical analysis of these criteria shows that the referendum fell short regarding the first two criteria whilst it could have done better as regards the last two. The final section discusses whether the criteria used for the analysis are too stringent, and what can be learned for future referendums.

\section{Defining the democratic legitimacy of a referendum}

To answer the question of how legitimate the EU membership referendum in the UK was requires a notion of legitimacy. When defining legitimacy, scholars typically look at input and/or outcome criteria (Scharpf 1999). Looking at the latter, whether staying or leaving the EU will produce just policies and improve everybody's welfare as well as grant the UK more sovereignty and democracy, is a very important issue. Indeed, not a few consider it is so 
important that it should not have been the object of a referendum in the first place. However, it does not say much about whether the process leading to the referendum result was democratically legitimate. Instead, it is the quality of the democratic process that is crucial to ensuring that conflicts can be managed peacefully and for losers to be able to accept the result of the referendum, if only in a preliminary way. Therefore, democratic legitimacy is largely a matter of input rather than outcome (Buchanan 2002).

How, then, can we define input legitimacy? A common definition is that input legitimacy derives from a process in which all relevant parties are entitled to have their views and interests treated with equal respect and concern (Scharpf 1999). In the context of the referendum, for this to be the case, we need to take into account the following criteria: (1) how the franchise is defined, (2) the presence of clarity, (3) the amount and quality of information, and (4) the quality of public debate. These criteria are - as I shall argue - what makes input legitimacy of a referendum, as defined above, possible. Let us look at each of these in turn.

\subsection{Franchise}

In order to address whether the process entitled 'all relevant parties' to have their views expressed, we must first of all look at the franchise which answers the question of "who belongs to the people?' The standard view of political community is that entitlements to a say over collective matters should follow membership, formalized as citizenship. Importantly, citizenship has in modern democracies been linked to nation-states. This standard view is well reflected in the stakeholder account of political rights and obligations, in which the claim to being a citizen of a given political community belongs to those whose freedom and rights are inherently linked to the collective self-government and flourishing of this polity over time (Bauböck 2015). On this account, one would include those individuals in the franchise who enjoy citizenship of the given country.

However, due to increasing social and political entanglements as well as changing ethics, this reading of membership in a political community has been increasingly challenged, and a number of scholars argue for an extension of participation rights to other persons, such as non-citizens, who were previously not included in the franchise. 
Some authors have pled in favour of the all-affected principle (AAP). The principle suggests that those whose interests are being affected by a decision should be able to influence the making of that same decision (Goodin 2007). The AAP thus determines the scope of the people on the basis of the scope of the decision at hand. The obvious problem with this approach is its 'over-inclusiveness' (Goodin 2007, pp. 49, 57). The latter is perhaps not surprising given the cosmopolitan drive of the supporters of the AAP, but leaves us uncertain as to whose interests are actually being affected. Also, one can easily see that for many, if not most, decisions, some citizens' interests will be affected more than other citizens' interests, thereby introducing the challenge of having to weigh interests and allocating proportional voting rights (Miller 2009, p. 216; Warren 2017, p. 9).

Other scholars have argued in favour of the all-subjected principle (ASP). Crucially, and unlike the AAP, the ASP links democracy to the nation-state and argues that 'all those subjected to political rule within its boundaries ought to have a say in its making' (Näsström 2011, p. 117), a proposition that comes fairly close to the idea of "no taxation without representation'. The ASP as a result has been used to demand greater political inclusion, mostly of migrants, within the nation-state. For if resident aliens are obliged to abide by the rules of a state, why should they not have the right to participate in its decisions (Gould 2006, p. 49)? Anything else, so the argument runs, results in the 'effective disenfranchisement' (Benhabib 2004, p. 215) of permanent residents from national politics.

I will propose that a mix of the stakeholder principle and the ASP should have prevailed in the British in/out referendum in order for all relevant views and interests to be treated with equal concern. The mix results from the fact that the stakeholder perspective appears too narrow whereas the ASP appears too broad. Why is this so?

On the one hand, the strong link that the former establishes between presence, attachment to the political community and citizenship rights and obligations is not fit for purpose. Some might object that the franchise ought to be linked in a straightforward way to citizenship, so that only the British people decide on their membership of the EU and no one else. However, in a context where one of the leading legal rules in the EU is freedom of movement between (participating) states, this very principle has created reasonable expectations for EU citizens resident in the UK. EU law entitled EU citizens who have settled in the UK to reside there without having to naturalise (and to vote for European and local elections). Without a willingness to legislate, prior to the vote, that permanent resident rights established prior to a potential Brexit should continue after Brexit, those expectations could 
not be met. As a result, the agreement of the British people to free movement under the EU Treaties implied an obligation to include EU residents in the UK in the referendum on EU membership, similar to the inclusion of EU citizens in the Scottish independence referendum in 2014. The potential objection that citizens moving to the UK freely undertook the risk of the UK using Article 50 to depart from the EU is at best valid for those who moved to the UK after the Lisbon Treaty entered into force in 2009, since this article did not exist before. But even after 2009, can we reasonably expect citizens to be aware of this specific article?

Others might object that extending the stakeholder principle to those EU citizens resident in the UK is not sufficient and that the UK is not the relevant polity for the stakeholder principle (which instead is the EU). However, when applying normative criteria to real world processes, one needs to take the concrete context of those processes into account. In the present case, that means taking into account a) that the nation-state has not lost its meaning and function to such a degree that governments and citizens would be prepared to let individuals participate in political choices about their 'own' country when those individuals do not even live on the respective territory, b) that the EU allows for a member state to leave the EU 'in accordance with its own constitutional requirements' as per article 50, without consultation of the other member states or their populations, and c) that we have freedom of movement in the EU and that EU citizens living in the UK at the time of the referendum therefore had established rights.

On the other hand, the weak link that the ASP sees between presence, attachment to the political community and citizenship rights and obligations does not accept that people move (travel) in different capacities. For instance, some citizens will have spent their holidays in the UK over the $23^{\text {rd }}$ of June 2016 and as such were subject to British law on UK territory. Certainly, that should not have entitled them to a vote. The same can be said about short-term guest workers, who by definition will have left long before any of the consequences of the vote will materialise, as well as potential future migrants who have not become residents in the UK yet and as a result have not established rights.

In contrast, EU citizens residing in the UK are directly and strongly affected by the decision, particularly in the case of a leave vote. In the case of a leave vote, lives will be and have already been affected by the same changing economic conditions, e.g. living costs as well as employment opportunities (think of firms that are relocating to other EU member states) as everyone else living in the UK. In addition, however, EU citizens residing in the 
UK are a special case. Many of them came and settled because of free movement entitlements within the EU. With a leave vote, their lives can be and have already been affected substantially in terms of rights as well as employment opportunities, possibly prompting families to move to other EU member states. Given this result, they should have been included in the franchise.

\subsection{Clarity}

Let us move on to the next criterion that enables democratic participation. In order for all relevant parties to be able to express their views and interests, it is crucial that there is clarity about the policy at stake. In our case, this means that the question to be asked in the referendum needs to be clear (LeDuc 2015: 141). Likewise, what follows from the chosen answer to the question needs to be clear to voters (Renwick et al. 2018: 546). Clarity exists when 'the various sides of an argument are well known and well established in the public discourse' (LeDuc 2015: 142-143). If asked to tick a box without knowledge of what each option represents, one is not casting a meaningful vote. Indeed, these principles are also laid out by the British Electoral Commission: 'Informed voters are fundamental to a well-run referendum, and this means that those eligible to vote (...) should be able to understand the referendum question, the possible outcomes and the campaign arguments' (Electoral Commission 2016: 37). Clarity of the question as well as the implications of either choice is a crucial precondition for a meaningful debate during the campaign as well as a meaningful vote.

\subsection{Information}

Third, the amount and quality of information matter for a legitimate process. Citizens need to be informed about politics to hold informed opinions, to participate in politics and make choices that align with their interests (Delli Carpini and Keeter 1996; Milner 2002). In order for the process to be fair and impartial with regard to the different views, spending in the campaign needs to be regulated so as to ensure that neither side over-spends and has similar chances to put an argument forward. It is furthermore important that the information be circulated evenly, assuring that voters receive information from both sides and can as a result make an informed decision. Media has a crucial part to play in assuring that information is reported in a balanced way and that the arguments of either side are made available to the 
public. However, information need not only be available; it also needs to be of high quality, which one can define as information that 'is accurate, impartial, accessible to as many people as possible, and relevant to people's concerns' (Renwick et al. 2018: 549). For voters to make a free choice, trustworthy information should be readily available to them. If voters' choices are based on misinformation or deceit, they cannot be sure to actually vote in a manner that best serves their own interests. Furthermore, their capacity to hold office holders and campaigners to account will be reduced.

\subsection{Public Debate}

The last criterion is public debate. Public debate is crucial as it is here where persuasion can occur as arguments are exchanged and defended and can be weighed against one another. Public debate should be organized around alternative conceptions of the public good. It is where information, views, arguments and counter arguments on relevant issues ideally are expressed and tested as well as channelled into administrations. As such it serves different purposes. Public debates can act as processes that convey information. Given no individual alone possesses all the relevant information about any given policy, sharing information in public debates is important. Likewise, the different views that actors hold are rarely if ever known by the larger public, rendering a public sphere and debate where they can become known essential. Public debate thus reveals issues that bear significance for the whole society and contributes to the solution of problems. Indeed, these functions of public debates resonate well with Kant's idea of debate as a tool of enlightenment. Furthermore, public debate should feed into parliamentary debates as well as government policies. If there is no public debate, then the link between society and government and state would be interrupted and democracy would become elitist. As such, public debates also help to hold MPs and administrations to account. It is through these different functions that public debate contributes to democratic legitimacy (Habermas 1962). These days, public debate takes place mostly through the mass media, but also increasingly through social media, as well as public meetings, which indicates that there are different forums with at least in part different publics, rendering it more difficult to realise the above described ideals. 
Having established the four criteria against which to assess the democratic legitimacy of the referendum process, I will now move on to an empirical assessment of how far it lived up to them.

\section{Assessing the democratic legitimacy of the Brexit referendum}

\subsection{The franchise}

The franchise for the 2016 referendum on UK membership of the European Union was defined in the EU Referendum Act 2015. It provided that the franchise be based on the general election franchise, with provision made also for members of the House of Lords to vote, along with electors in Gibraltar. In so doing, the definition of the franchise followed the stakeholder account sketched above. Even from an all-subjected principle perspective, the exclusion of those expatriates who have not lived on British territory for more than 15 years seems entirely justifiable.

However, the Referendum Act reduced the electorate in a less justifiable way, i.e. by excluding EU citizens resident in the UK, meaning that 2.15 million adult EU citizens (Fox et al. 2016: 507), most of whom pay taxes in the UK, were denied universal and equal suffrage (Low 2017: 2). As a result, some of those 'most likely to be strongly affected by the decision - long-term external citizens, many of whom rely on EU citizenship rights to reside in the host state, non-UK EU citizens resident in the UK and younger people - were precisely those deprived of a voice' (Shaw 2017: 567).

Why was that so? The House of Commons Briefing Paper 07212, published on 3 June 2015, told all MPs and members of the House of Lords that the results of a referendum would not need to be implemented (House of Commons 2015: 25) and thus would not be binding on Parliament or government. This was 'the reason given for not extending the franchise appropriately.' (Grayling 2017: 190). Another reason for letting the Brexit fraction of the Conservative party define the franchise in the way that suited them best - namely excluding British expats, 16-17 year-olds and EU citizens, the inclusion of whom would have favoured a 'Remain' vote - was that nobody expected Leave to win (see Shipman 2016).

As a result of the definition of the franchise, not all relevant parties could see their views and interests represented with equal respect and concern. As a result, the input legitimacy of the process suffered. 


\subsection{The presence of clarity}

The referendum question read 'Should the United Kingdom remain a member of the European Union or leave the European Union?' The question as such is very clear. The trouble is that 'Remain' or 'Leave' never were just one option. For instance, 'Leave' is a term for a number of alternatives, such as staying in the single market and/or the customs union, Norway, Canada, WTO framework, etc. Once we look at the different Leave options, we see that a majority for 'Leave' does not express the will of the people in respect of any one of those alternatives. Research from the Electoral Commission has found that $45 \%$ of polled people found it 'difficult to access information about what would happen in the event of a Leave vote' whereas 41\% found this easy (Electoral Commission 2016: 44). These numbers suggest that the public were deprived of clarity about what would happen in the case of a 'Leave' vote, thereby rendering a meaningful vote difficult. Let me illustrate this point with a different example.

Imagine 40 per cent of the population is vegetarian, 30 per cent loves pork but abhors beef, and the remaining 30 per cent love beef but cannot eat pork. A vote on the question 'who wants to eat meat tonight?' could yield a 60 per cent majority. Yet both the pork and the beef options are rejected by 70 per cent of the population. The reason is simple: 'meat' is not actually a real option. 'Meat' means something different to different voters, and the 60 per cent majority in favour of 'meat' is the sum of mutually incompatible beef and pork eaters ${ }^{2}$. To make things worse, any skilled politician can evade criticism of the 'meat' option by switching from one definition to the other as convenient.

Transferred to the in/out referendum this means that the vagueness of the 'Leave' option allowed its campaign to cast the widest net of all, encouraging each voter to keep their most favourable version of Brexit in mind, however far that may have been from reality. It allowed hard and soft Brexiteers, free-market fundamentalists and protectionists, open-door internationalists and xenophobes to all add their votes together (Grayling 2017: 194), creating a coalition of incompatible voters. One might object that at a higher level of aggregation, most 'Leave' voters agreed with the slogan of 'taking back control' so as to achieve fuller sovereignty somehow and also be able to control borders. However, this 'agreement' rested by and large on a false knowledge of the status ante quo and/or false expectations as to what

\footnotetext{
${ }^{2}$ We know from related research that having more than two options for voters to choose from comes with its own problems (Weale 1999: 132-37).
} 
might be achievable in terms of sovereignty and border control post Brexit and/or different degrees to which voters agreed to the slogan as well as the type of policy they would like to see implemented post Brexit. Consequently, most 'Leave' voters will not get the Brexit they thought they voted for.

In sum, the question of the referendum was not answerable because the implications of either outcome were unclear, and the different alternatives were not sufficiently specified (Allen 2018: 110; Renwick et al. 2018: 546). Whilst there was a (tight) majority for some version of Leave, we do not know the real preferences of those who voted Leave. In other words, the first referendum hid the different preferences that supported Leave. As a result, the democratic legitimacy of the process was harmed.

\subsection{The amount and quality of information}

As discussed above, one of the preconditions for a fair campaign is that both sides of the campaign have access to similar amounts of funding. In the present case, campaigners were 'subject to the PPERA ${ }^{3}$ regulatory framework which places limitations on spending by campaigners and provides transparency about sources of funding' (Electoral Commission 2016: 9). For each campaign, regulation foresaw a spending limit of $£ 7 \mathrm{~m}$. It has in the meantime come to light that Vote Leave spent at least $£ 625,000$ over its spending limit, funnelling said amount into BeLeave, the youth arm of the Leave campaign. The over-spent cash went into online advertising, targeting people based on individual psychological profiles. According to evidence heard by a House of Commons Committee in March 2018, those profiles were built through Facebook and other data, without consent or knowledge of UK voters. They were first sold to Cambridge Analytica LLC and then to a Canadian corporation, Aggregate IQ Ltd, hired by Vote Leave, to target UK voters ${ }^{4}$. In July 2018, the Electoral Commission confirmed that Vote Leave had broken electoral law, not least by breaking spending limits. We cannot know the impact that the spending fraud of Vote Leave

\footnotetext{
${ }^{3}$ The Political Parties, Elections and Referendums Act 2000

4 https://www.theguardian.com/politics/2018/mar/26/pressure-grows-on-pm-over-brexit-cambridgeanalytica-scandal-theresa-may
} 
had. What we do know is that there was fraud, which decreases the democratic legitimacy of the process.

Turning to the amount of information, voters had access to a multitude of sources of information, both online and offline. Online sources consist of the websites of media, government bodies, academia, think tanks and social media. Offline sources consist of printed media, television, political events, and peers. Though it is fairly safe to assume that the average voter will not explore all of these sources to inform themselves, it is also fair to assume that taken together, these different sources produced a sufficient amount of information, though as discussed above, perhaps not necessarily the relevant information. Indeed, when asked, $84 \%$ of the respondents said that they knew 'a great deal' $(34 \%)$ or 'a fair amount' (50\%) about what the referendum was for (Electoral Commission 2016: 44). However, when respondents were asked whether they had enough information to be able to make an informed decision, only $62 \%$ agreed whereas $28 \%$ disagreed (ibid., 45 ).

This brings us to the quality of information, for what is having a lot of information good for if it does not allow voters to make an informed decision? As is known, the campaigns were plagued by little lies, half-truths and misinformation (Renwick et al. 2018: 546). The most prominent example of misleading the public is the $£ 350$ million a week that Boris Johnson and others suggested would go to the NHS once the UK would have left the EU. It has become clear that this will not happen. By way of another example, a key them of the Leave campaign was the idea of 'taking back control' and restoring a classic notion of Parliamentary sovereignty. This slogan was based on a false characterisation of the pooling of sovereignty that membership of the EU involves. Whilst it is true that the Court of Justice of the European Union can de facto overrule national courts and national Parliaments, it is also true that Parliament had previously decided to give away some of its 'sovereignty' to the EU, because it was of the view that to get on in a globalising world, it is necessary to sign up to international treaties, not least with immediate geographic neighbours. In fact, even strong Leave supporters have recognised that the slogan was 'a misleading half-truth' (Rose, 2018: 13). On the other side, the Remain campaign repeatedly used unverified numbers to forecast an economic breakdown in the case of exiting the EU.

Indeed, the Electoral Commission received more than 1,000 complaints from the public about the content of campaign material. Furthermore, only $34 \%$ of the respondents of post-referendum research agreed with the statement that the conduct of the campaigns was 
fair and balanced, with a mere 12\% agreeing strongly (Electoral Commission 2016: 47). The main reasons given for considering that the conduct of the campaign was not fair and balanced were that the campaign was 'one-sided/unbalanced/biased/partial' (31\%) and the information was 'inaccurate and misleading' (31\%) (ibid.). Indeed, supporters of both sides of the campaign have acknowledged that 'truth was badly compromised in much of the campaign' (Low 2017), thereby further reducing the democratic legitimacy of the process. Richard Bellamy considers that the fact that the campaigns involved half-truths and misinformation is not relevant given voters would be used to it from regular elections and thus even expect it (Bellamy 2018: 4). However, the main difference compared to regular elections of course is that the in/out referendum was a one-off 'event' with a priori no opportunity to hold the leading figures of either campaign to account. Therefore, there was even less incentive to act in a truthful way.

The media are the source of a vast amount of information received by the public, and it is their responsibility to inform and educate in an unbiased way, as well as to interpret. It has been suggested that the media did not do enough to retract lies, misinformation or unsubstantiated insinuations (Seaton 2016). Even the BBC has seen itself confronted with criticism for treating all arguments 'as of equal value, giving equal airtime to unequal arguments' (Parker 2017: 7). As a result, the arguments that were presented in debates often lacked the necessary proportion and expert critique, thus leaving half-truths unexplored and insufficiently countered (Seaton 2016: 335-336), something which was dubbed a 'fairness bias' by Timothy Garton Ash ${ }^{5}$.

Some might say that all the necessary information was available, not least through fact-checking provided by the BBC and The Guardian, and people simply did not want to know or listen (Bellamy 2018). However, the average citizen will not go to the EU websites (or even the BBC) to find out whether a claim made by either side of the campaign is true or not. Citizens depend on party actors and on the media to give them cues, also in regard to European integration (Hobolt and de Vries 2016: 422). To some extent, they do not even go as far as that and instead rely on peers in their echo chambers - though again, cues there will have more often than not originated in some media outlet, and will often revolve around what some politician has said. Therefore, what party actors and the media offer in terms of

\footnotetext{
${ }^{5}$ https://www.theguardian.com/commentisfree/2016/apr/01/bbc-brexit-too-timid-impartial-on-eu-notenough
} 
information is highly important, though it leaves unanswered the question of which responsibility voters have to inform themselves properly.

In sum, the assessment of this criterion is mixed. There seems to have been some overspending by Leave, thereby challenging the idea that both campaigns had the same chances to convince voters. Still, it cannot be denied that a wealth of information was available on either side of the campaign, though it was not always put to good use. Again, this is likely linked to the absence of clarity as to what leaving the EU might actually mean. Overall, one certainly can argue that the democratic process was harmed both by the fraud as well as the half-truths and misinformation involved. This leads our discussion to the last criterion of input legitimacy, i.e. the quality of public debate.

\subsection{The quality of public debate}

The media also has an important role to play so far as public debate is concerned. By and large, they provide the forum in which different arguments are reported and exchanged. Did the media make arguments from either side available to the public? It is possible to claim that overall, one could find different arguments in the media. However, there are two caveats.

First, whereas in broadsheets one could find arguments both in favour and against staying in the EU, the arguments put forward in tabloids were much more unidirectional and less balanced. As a result, the audience of the pro-Leave tabloids was mostly exposed to onesided, Eurosceptic arguments. Second, of the nine main national daily newspapers, five supported the Leave campaign. These were the Sun, Daily Express, Daily Star, Daily Mail, and Daily Telegraph. Three newspapers were mostly pro-Remain: The Guardian, Daily Mirror, and the Financial Times. Of these only the Mirror has a circulation that compares with that of the Leave newspapers. The other main national daily, The Times, adopted a more or less neutral position (Levy et al. 2016). As a result, 80 per cent of people who regularly bought a daily newspaper bought a title favouring Leave (Levi et al. 2016), implying that the Eurosceptic discourse of the main tabloids reached a much larger audience. The combined effect of these two factors - unidirectional reporting of tabloids and wider reach of tabloids was that, of the referendum-focused articles that reached their audience, 48 per cent were proLeave and just 22 per cent pro-Remain (Levi et al. 2016) ${ }^{6}$. This perhaps does not come as a

\footnotetext{
${ }^{6}$ That said, research findings are inconclusive as to the influence of newspapers on voting choice.
} 
surprise given most British tabloids have run, for several decades, a campaign against the EU (Daddow 2012), as was documented in June 2016 by the Economist ${ }^{7}$.

When looking at the quality of the public debate, we obviously should not only look at the media, but also at those who provide the cues, more often than not, that the media and others will then pick up, i.e. political leaders. Did they discuss their arguments against each other, in public? This happened to some degree in televised debates, and when prominent representatives of either side made public speeches. However, politicians mostly put forward an argument about the advantages of their respective perspectives - or, on the Remain campaign, the disadvantages of leaving the EU - without directly engaging with each other's arguments or the 'facts' that the other side used. Instead, we witnessed a cherry-picking of numbers and arguments depending on which perspective was adopted. Let us illustrate the point by means of two prominent examples. The first is the question of whether or not the UK can manage the scale of immigration into its territory while a member of the EU. Leave suggested it cannot and that being a member of the EU meant signing up to the principle of free movement for EU nationals. Whilst this is correct, it missed the point that migration to the UK is more than just intra-EU migration. 'Remain' in turn said that if the government chose to, the UK would be able to turn EU nationals away for reasons of public security or health. Whilst this is also correct, it did not really engage with the argument put forward by the Leave side. The second example concerns the amount of legislation coming from Brussels. 'Leave' claimed that up to 60 per cent of all the UK's laws are made in Brussels whereas 'Remain' would suggest that the number is nearer to 13 per cent. Interestingly, both sides got their numbers from the same source (a 2010 analysis by the House of Commons Library), and both claims were equally correct. It all depends on what is included in the definition of EU law. The estimates at the higher end of the spectrum included EU rules that are not laws in a meaningful sense, such as administrative decisions, and regulations that are not relevant to the UK. However, this difference was not explained to the public, and arguments did not get properly discussed against each other, reducing the democratic legitimacy of the process further.

\footnotetext{
${ }^{7}$ The Economist published the chart 'Lies, Damned Lies, and Directives', which documents decades of flat-out lies about EU regulations that were published in the tabloid press:
}

https://www.economist.com/blogs/graphicdetail/2016/06/daily-chart-15, accessed 5 February 2018. 
Let us sum up. The first criterion, the definition of the franchise so as to include all who are permanently subject to British law on British territory and over 16, was not met. The second criterion, the presence of clarity, was met half-way. Whereas the referendum question itself was clear, the implications, particularly of 'leave,' were anything but. As a result, it was difficult if not impossible to make an 'informed decision'. The third criterion was the amount and quality of information. We know that there has been over-spending by the Leave campaign. Information was accessible to many people and as such, there was a sufficient amount of information. However, it was not always accurate nor impartial. Instead, voters were exposed to a series of half-truths as well as misinformation, and print media was heavily biased in favour of Leave. As regards the fourth and final criterion, public debate, this might be the criterion that comparatively speaking scores best amongst the four criteria. Different arguments were made, both by politicians and by the media. However, the quality of the debate was poor because there was a cherry-picking of arguments rather than looking at the question of EU membership in a more holistic way, and arguments were not discussed against each other but in isolation.

In light of the above findings, the assessment cannot but be that the input legitimacy of the British membership referendum as defined in the context of this contribution was harmed, bearing in mind the caveat that the assessment was restricted to available secondary literature.

\section{Conclusion}

In this contribution, I have looked at the democratic legitimacy of the British in/out referendum of 2016. I have suggested that its legitimacy depends on certain criteria, namely the franchise, presence of clarity, amount and quality of information, and public debate. The empirical analysis of these criteria showed that the referendum fell short of the first two whilst it could have done better for the latter two.

One might ask whether the criteria I have put forward in this contribution are not too stringent. After all, we do not suggest that general elections are illegitimate if the foregoing 
campaigns (sender) included different bits of misinformation or when some voters (receiver) may have made their choice based on wrong information. Whilst these are fair objections, we need to recognize there are important differences between general elections and one-off referendums which change the game to some degree. If elected politicians hand over very important decisions to voters, then this comes with an even stronger responsibility on their part to stay truthful and not seek to manipulate the electorate. However, elected politicians have less of an incentive to remain truthful in referendum campaigns compared to general elections, given that referendums are one-off events and the politicians cannot be thrown out of office by voters if their recommendations prove flawed or false. In the present case, this argument weighs particularly heavily since leaving the EU will shut the door to renewed British EU membership for the foreseeable future whilst having a considerable, and probably negative, impact on the economy in the short to medium term. In other words, the fact that elected politicians cannot be held to account by voters after the vote increases the need for them to act in ways consistent with quite stringent criteria, such as those proposed here. To allow them to do otherwise can only diminish popular trust in representative institutions.

At the same time, handing over very important decisions to voters also places greater responsibilities and obligations on the electorate as well, not least the obligation to inform themselves more and better than they would do in the context of general elections. In representative democracy, voters are normally quite happy to delegate the responsibility to govern and steer to those very few elected politicians who, in turn, are happy to make it their full-time job and as a result have more information on specific policies than the average voter. In forms of direct democracy such as referendums, this duty to be informed and act responsibly lies both with elected politicians who have decided to hand over a decision to voters, and with the voters themselves. It is difficult to see how democratic legitimacy would pass a serious test if both sides did not accept this responsibility.

To conclude, let us briefly look at what can be learned from the recent British EU membership referendum. The single most important lesson is that governments should not call referendums if they cannot be very clear about what each option of the ballot paper involves. Cameron's commitment to a referendum did not come from a careful analysis of what an EU membership referendum would involve, what the implications of a 'Leave' vote might be, nor how leaving the EU could be implemented. Instead, he sought to appease his backbenchers, and prioritised winning the next general elections over carefully considering 
what a referendum on the EU might involve (Renwick et al. 2018: 546). The consequences of holding a referendum on an as important question without it having been clear from the start what 'Leave' would mean can be observed in British politics ever since. There was no clarity for voters what 'Leave' would entail, which allowed for a poor-quality campaign. Worse, not only has the country been utterly divided since the vote, but even MPs and the government struggle to know what type of Brexit they should deliver; this has led to widespread confusion, to the point that crashing out of the EU without any deal does not seem impossible at the end of 2018. In sum, 'a referendum is a mechanism for deciding between two options. It is not in itself a mechanism through which the form of those options can be developed' (Renwick et al. 2018: 547).

Second, and as regards the campaign, it might be worthwhile considering using deliberative forums and citizens assemblies more. In a political environment in which the media landscape is as polarised and ideological about an issue as the British tabloids are about the EU, and where citizens mistrust politicians to a high degree, it is worth experimenting more with forms of citizen education and enabling. Though only a few voters can ever participate in these forums, their results can be made broadly available, and might be trusted more by peers than what distant media or politicians claim.

Third, and finally, referendums in general, and in particular in democracies where they are used rarely, should be complementary to representative democracy and not substitute it. In the present case, Cameron's decision to hold a referendum on EU membership was driven by party-political goals. Instead, it should have been embedded in a discussion process in Parliament where government and opposition parties could have debated the problems they saw and how they might best be addressed, as well as which options should be put to the voter, if any.

\section{References}

Allen, N. (2018) Brexit means Brexit: Theresa May and post-referendum British politics, British Politics, 13(1), pp. 105-120.

Armstrong, K. (2017) Brexit Time. Leaving the EU - Why, How and When? Cambridge: Cambridge University Press. 
Bauböck, R. (2015) Morphing the Demos into the right shape. Normative principles for enfranchising resident aliens and expatriate citizens, Democratization, 22(5), pp. 820-839.

Bellamy, R. (2018) Was the Brexit referendum legitimate, and would a second one be so? European Political Science, https://doi.org/10.1057/s41304-018-0155-x

Benhabib, S. (2004) The Rights of Others: Aliens, Residents and Citizens. Cambridge: Cambridge University Press.

Buchanan, A. (2002) Political Legitimacy and Democracy. Ethics, 112(4), pp.689-719.

Chalmers, D. (2017) Brexit and the renaissance of parliamentary authority, The British Journal of Politics and International Relations, 19(4), pp. 663-679.

Clark, H.D., Goodwin, M. and Whiteley, P. (2017) Brexit. Why Britain voted to leave the European Union. Cambridge: Cambridge University Press.

Curtice, J. (2017) Why Leave Won the UK's EU Referendum, Journal of Common Market Studies 55(1), pp. 19-37.

Daddow, O. (2012) The UK media and 'Europe': from permissive consensus to destructive dissent, International Affairs, 88(6), pp. 1219-1236.

Dahl, R. A. (1989) Democracy and its critics. New Haven: Yale University Press.

Delli Carpini, M. X., and Keeter, S. (1996) What Americans know about politics and why it matters. New Haven, CT: Yale University Press.

Glencross, A. (2016) Why the UK Voted for Brexit: David Cameron's Great Miscalculation. London: Palgrave Macmillan.

Goodin, R. (2007) 'Enfranchising all Affected Interests, and its Alternatives.' Philosophy and Public Affairs, 35(1), pp. 40-68.

Goodwin, M. and Milazzo, C. (2017) Taking back control? Investigating the role of immigration in the 2016 vote for Brexit, The British Journal of Politics and International Relations, 19(3), pp. 450-464.

Gormley-Heenan, C. and Aughey, A. (2017) Northern Ireland and Brexit: Three effects on 'the border in the mind', The British Journal of Politics and International Relations, 19(3), pp. 497-511.

Gould, C. (2006) 'Self-Determination beyond Sovereignty: RelatingTransnational Democracy to Local Autonomy', Journal of Social Philosophy, 37(1), pp. 44-60.

Grayling, A.C. (2017) Democracy and Its Crisis. London: Oneworld publications.

Habermas, J. (1962) Strukturwandel der Öffentlichkeit: Untersuchungen zu einer Kategorie der bürgerlichen Gesellschaft. Frankfurt am Main: Suhrkamp. 
Hobolt, S.B. and de Vries, C.E. (2016) Public Support for European Integration, Annual Review of Political Science, 19, 413-32.

Hopkin, J. (2017) When Polanyi met Farage: Market fundamentalism, economic nationalism, and Britain's exit from the European Union, The British Journal of Politics and International Relations, 19(3), pp. 465-478.

House of Commons (2015) European Union Referendum Bill 2015-2016. Briefing Paper Number 07212, 3 June 2015.

LeDuc, L. (2015) Referendums and deliberative democracy, Electoral Studies, 38, pp. 139148.

Levi et al. (2016) UK press coverage of the EU referendum, Reuters Institute for the Study of Journalism, University of Oxford / Prime Journalism. Available at:

http://reutersinstitute.politics.ox.ac.uk/our-research/uk-press-coverage-eu-referendum, accessed 15 July 2018.

Low, A. (2017). In some respects the Brexit referendum was a violation of human rights. http://blogs.lse.ac.uk/europpblog/2017/02/09/brexitreferendum-human-rights

McHarg, A. and Mitchell, J. (2017) Brexit and Scotland, The British Journal of Politics and International Relations, 19(3), pp. 512-526.

Milner, H. (2002) Civic literacy. How informed citizens make democracy work. Hanover, NH: University Press of New England.

Näsström, S. (2011) The Challenge of the All-Affected Principle. Political Studies, 59(1), pp. 116-134.

Renwick, A., Palese, M. and Sargeant, J. (2018) Discussing Brexit—Could We Do Better?, The Political Quarterly, 89(4), October-December 2018.

Rose, R. (2013) Representing Europeans: A Pragmatic Approach. Oxford: Oxford University Press.

Shaw, J. (2017) The quintessentially democratic act? Democracy, political community and citizenship in and after the UK's EU referendum of June 2016, Journal of European Integration, 39(5), pp. 559-574.

Scharpf, F. (1999) Regieren in Europa. Effektiv und demokratisch? Frankfurt a.M. / New York: Campus.

Seaton, J. (2016) Brexit and the Media. The Political Quarterly, 87(3), pp. 333-337.

Shipman, T. (2016) All Out War: The Full Story of How Brexit Sank Britain's Political Class. Collins. 
Soares, A. (2016) Living Within and Outside Unions: the Consequences of Brexit for Northern Ireland, Journal of Contemporary European Research, 12(4), pp. 835-843.

Warren, M. E. (2017) The All Affected Interests Principle in Democratic Theory and Practice. IHS Political Science Series Working Paper 145.

Weale, A. (2018) The Will of the People. A Modern Myth. Cambridge: Polity Press. 